\title{
PRIMATA BESAR DI JAWA: SPESIMEN BARU GIGANTOPITHECUS DARI SEMEDO
}

\author{
GIANT PRIMATE OF JAVA: \\ A NEW GIGANTOPITHECUS SPECIMEN FROM SEMEDO
}

\author{
Sofwan Noerwidi ${ }^{1}$, Siswanto ${ }^{1}$, Harry Widianto ${ }^{2}$ \\ ${ }^{1}$ Balai Arkeologi Yogyakarta, ${ }^{2}$ Direktorat Pelestarian Cagar Budaya dan Permuseuman \\ noerwidi@arkeologijawa.com
}

\begin{abstract}
In 2014 there was found two "enigmatic" specimens of mandible, which named as Semedo 3417 and 3418. Both mandibles are morphologically similar but twice bigger than common primate's jaw. In this research, we use morphology and morphometric analysis to determine the species identity and taxonomic position of those specimens. For comparison study we use some samples from Homo erectus (Java and China), Gigantopithecus (blacki and bilaspurensis), Australopithecines (robust and gracile). Based on morphology and morphometric characters on the mandible and teeth, it is concluded that Semedo specimen tends to be close to Gigantopithecus blacki. The discoveries of Gigantopithecus fossil in Java has implication on some research problem, especially regarding the adaptation pattern of this species which known only found at high latitudes environment. Furthermore this discovery has reinforced the perspective that tropical environment has a very high biodiversity, particularly on primate fossils.
\end{abstract}

Keywords: Morphology, Morphometric, Taxonomy, Gigantopithecus blacki, Semedo, Java.

\begin{abstract}
ABSTRAK
Pada tahun 2014 ditemukan dua spesimen mandibula yang "enigmatic", dengan nama Semedo 3417 dan Semedo 3418. Kedua mandibula tersebut secara morfologis mirip dengan bentuk rahang primata pada umumnya, namun berukuran dua kali lipat lebih besar. Dalam penelitian ini dilakukan studi morfologi dan morfometri guna mengungkap identitas spesies dan posisi taksonomi spesimen tersebut. Sebagai pembanding digunakan sampel dari populasi Homo erectus (Jawa dan China), Gigantopithecus (blacki dan bilaspurensis), Australopithecines (kekar dan ramping). Hasilnya diketahui bedasarkan karakter morfologi dan morfometri pada mandibula dan gigi cenderung dekat dengan populasi Gigantopithecus blacki. Penemuan fosil Gigantopithecus di Jawa ini membuka sejumlah permasalahan penelitian khususnya mengenai pola adaptasi makhluk yang selama ini diketahui hanya ditemukan di garis lintang tinggi. Selain itu, penemuan ini semakin meneguhkan pandangan bahwa lingkungan Tropis memiliki keragaman hayati yang sangat tinggi, khususnya fosil primata.
\end{abstract}

Kata Kunci: Morfologi, Morfometri, Taksonomi, Gigantopithecus blacki, Semedo, Jawa.

Tanggal masuk : 8 Mei 2016

Tanggal diterima : 31 Oktober 2016 


\section{PENDAHULUAN}

Situs Semedo mulai dikenal sejak tahun 2005 setelah terjadi erosi akibat terbukanya lahan situs yang semula tertutup oleh vegetasi hutan jati. Situs ini berada di area milik PT. Perhutani yang secara administratif terletak di Desa Semedo, Kec. Kedungbanteng, Kab. Tegal, Propinsi Jawa Tengah. Penelitian eksplorasi di situs Semedo mulai dilakukan oleh Balai Arkeologi Yogyakarta bekerjasama dengan Dinas Pendidikan dan Kebudayaan Kabupaten Tegal, pada tahun 2005 (Widianto dan Hidayat, 2006) (lihat Gambar 1.). Hasil penelitian tersebut memberikan informasi awal mengenai potensi signifikan Situs Semedo baik secara arkeologis, geologis maupun pelaontologis, sehingga dapat disejajarkan dengan situs-situs serupa yang dapat melengkapi pandangan kita terhadap rekonstruksi prasejarah Kuarter di Pulau Jawa sejak paling tidak dua juta tahun yang lalu.

Akhirnya, pada bulan Mei tahun 2011 ditemukan fragmen atap tengkorak manusia purba yang pertama dari Situs Semedo oleh Pak Dakri, seorang warga lokal yang aktif dalam usaha pelestarian situs tersebut. Berdasarkan hasil analysis Widianto (2011), dapat diketahui bahwa fragmen atap tengkorak tersebut termasuk dalam anggota kelompok Homo erectus tipik (classic), yang berumur sekitar 0.7 juta tahun lalu (Widianto, 2011). Walaupun demikian, karena sifatnya yang merupakan temuan permukaan, maka pada saat penemuan itu lokasi pengendapan asli dari fosil "Semedo 1" belum dapat diketahui secara pasti.

Berdasarkan penemuan fosil mausia purba ini maka lengkaplah Situs Semedo sebagai salah satu situs Hominid di Jawa dengan jejak budaya dan lingkungan purbanya. Setelah terhenti sejenak sejak tahun 2008, pada tahun 2013 Balai Arkeologi Yogyakarta kembali mengadakan penelitian di Situs Semedo. Hasil yang diperoleh sangat signifikan, karena selain menambah kuantitas juga menambah kualitas data, terutama setelah ditemukannya beberapa spesies yang sangat langka, maupun spesies baru yang belum pernah ditemukan di situs Plestosen lainnya (Siswanto, 2013).

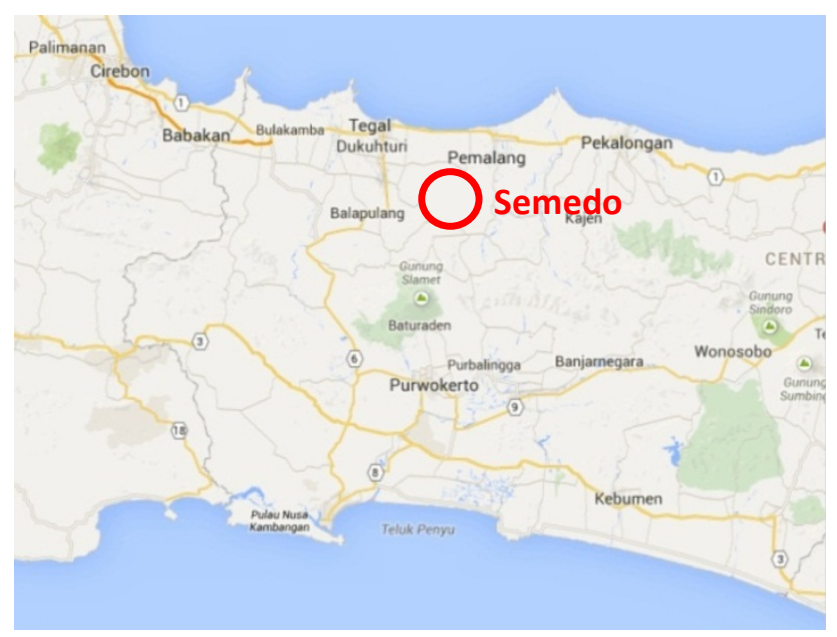

Gambar 1. Keletakan Situs Semedo di Kabupaten Tegal (Sumber: Penulis) 


\section{PENEMUAN BARU DI SITUS SEMEDO}

Berdasarkan hasil survei pada tahun 2014, Situs Semedo meliputi areal paling tidak seluas $4 \mathrm{x}$ $4 \mathrm{~km}$ persegi, dengan konsentrasi temuan terpadat berada di puncakpuncak perbukitan serta meander dan teras sungai resen. Namun ada perbedaan karakter pada kedua lokasi penemuan tersebut. Temuan yang berada di puncak-puncak bukit biasanya memiliki konteks yang baik dengan formasi batuannya, sedangkan temuan yang berada pada meander dan teras sungai resen memiliki konteks yang kurang jelas stratigrafinya. Selain itu pada penelitian tersebut juga ditemukan lokasi yang diperkirakan sebagai tempat pengendapan asli tengkorak Homo erectus "Semedo 1", yaitu berada di sisi utara salah satu puncak Bukit Tirem (Siswanto, 2014). Pada penelitian berikutnya, direncanakan akan dilakukan ekskavasi sistematis untuk mengetahui konteks litologis, kronologis, paleontologis, dan arkeologis temuan fosil manusia purba ini. Sehingga, dapat menjawab permasalahan mengenai kronologi manusia purba, serta konteks budaya dan lingkungannya pada Kala Plestosen di Situs Semedo, Tegal.

Penelusuran jejak budaya manusia purba di Situs Semedo hingga tahun 2014 telah berhasil mengidentifikasi sebanyak 799 buah alat lithic yang berciri teknologi paleolitik. Berdasarkan bahan bakunya sebagian besar berasal dari jenis batuan rijang (chert). Selain itu, ada juga sebagian kecil artefak yang terbuat dari jenis batuan kuarsit, basalt, batupasir, dan andesit. Secara umum, artefak-artefak tersebut dapat dikelompokan menjadi tiga macam, yaitu; artefak batu inti, artefak serpih, dan artefak lainnya yang terlibat dalam proses produksi alat batu. Dalam hal keragaman artefak yang ditemukan sangat signifikan, setidaknya terdapat lima macam artefak batu inti dengan karakter teknologi dari periode paleolitik, yaitu kapak perimbas, kapak penetak, kapak genggam, bola batu dan polyhedral (Noerwidi dan Siswanto, 2014; Siswanto, 2014). Berdasarkan pada kualitas dan kuantitas artefak paleolitik yang ditemukan, maka jejak budaya Homo erectus atau manusia purba di situs Semedo menjadi semakin nyata.

Identifikasi temuan
paleontologi berupa fosil-fosil vertebrata dan invertebrata di Situs Semedo memperoleh hasil signifikan yang menunjang rekonstruksi sejarah hunian di situs tersebut. Tercatat 2080 fosil yang terdiri dari fosil vertebrata dan fosil invertebrata teridentifikasi hingga tahun 2014. Keragaman jenis temuan fauna di Situs Semedo yang bervariasi menunjukkan habitat atau kondisi lingkungan yang beragam (Siswanto, 2014). Salah satu jenis vertebrata darat yang paling banyak adalah Probocidea, selain juga Bovidae, Cervidae, dan Chelonia. Hasil analisis komparasi morfologi dan morfometri terhadap fosil Proboscidea dapat diketahui bahwa di situs tersebut terdapat spesies Sinomastodon bumiayuensis, Stegodon trigonocephalus, Stegodon sp. ("pygmy"), Stegodon hypsilophus, Elephas (Archidiskodon) planifrons, dan Elephas Hysudrindicus. Potensi ini memperlihatkan bahwa Situs Semedo merekam sejarah perkembangan dan perubahan 
lingkungan yang cukup panjang, serta berkaitan erat dengan konteks ekologi yang mengindikasikan kehadiran manusia purba di kawasan ini (Siswanto dan Noerwidi et.al., 2014).

Temuan fenomenal lainnya yang dihasilkan dalam penelitian Balai Arkeologi Yogyakarta (2014) adalah dua spesimen mandibula yang "enigmatic", dengan nomor temuan Semedo 3417 dan Semedo 3418. Kedua mandibula ini secara morfologis mirip dengan bentuk mandibula primata, namun berukuran lebih besar sekitar dua kali lipat dari ukuran primata pada umumnya. Jika hanya didasarkan pada pengamatan sepintas, belum dapat diketahui dengan pasti jenis spesies dari primata misterius ini. Berdasarkan pada permasalahan ini, maka perlu dilakukan studi yang lebih mendalam mengenai fosil rahang beserta gigi-geligi primata dari Semedo tersebut guna memastikan jenis spesies dan posisi taksonominya yang berguna bagi pemahaman prasejarah Kuarter di Jawa.

\section{METODE PENELITIAN}

Penelitian mengenai sisa spesimen primata besar ini bersifat deskriptif komparatif dengan cara mendeskripsikan data secara sistematis untuk kemudian dilakukan analisis perbandingan dengan data dari penelitian serupa yang pernah dilakukan di Jawa pada khususnya maupun di kawasan sekitarnya. Data utama yang dimaksud dalam penelitian ini adalah fosil mandibula dan gigi-geligi molar dari spesimen bernomor temuan Semedo 3417 dan
Semedo 3418 yang ditemukan di Situs Semedo. Sedangkan data pembanding akan menggunakan data sejenis hasil studi terdahulu pada Sinanthropos pekinensis (Homo erectus pekininsis China) oleh Weidenreich (1945), Gigantopithecus blacki oleh von Koenigswald (1952),

Gigantopithecus bilaspurensis oleh Simons dan Chopra (1969), Howell (1969), Australopithecus (gracile) dan Australopithecus (robust) I Paranthropus oleh Frayer (1973), dan Pithecantropus erectus (Homo erectus erectus Java) oleh Widianto (1993).

Deskripsi dilakukan secara kualitatif terhadap karakter morfologi yang mencakup karakter bentuk (form) dan aspek metrik (shape) yang diaplikasikan dalam berbagai variable pengukuran (dimension) (lihat Tabel 1.). Guna keselarasan dengan kajian komparasi yang akan dilakukan dalam penelitian ini, maka digunakan metode deskripsi morfologi dan morfometri yang pernah dilakukan oleh para peneliti sebelumnya, yaitu Morant (1923), Martin dan Saller (1957), Kaifu (1997) dan Bulbeck dan O'Connor (2011). Karakter morfologi mandibula meliputi bentuk umum mandibula berupa bentuk corpus, serta jejak karakter anatomis yang masih dapat diamati pada norma lateral dan norma medial. Kemudian karakter morfologi gigi meliputi: dentin, tonjolan occlusal pada mahkota (cuspic), pola rekahan (fissure) di antara cuspic, bentuk pulpa (jika nampak), dan tingkat keausan gigi-geligi (White dan Folkens, 2005). 
Tabel 1. Definisi variabel studi morfometri mandibula

\begin{tabular}{llll}
\hline No. & Singkatan & \multicolumn{1}{c}{ Variabel* $^{*}$} & \multicolumn{1}{c}{ Referensi } \\
\hline $\mathbf{1}$ & H P4 & Tinggi Corpus pada Level P4 & H at P4 CH, (Kaifu, 1997) \\
$\mathbf{2}$ & H M1 & Tinggi Corpus pada Level M1M2 & H at M1 CH, (Kaifu. 1997) \\
$\mathbf{3}$ & H M2 & Tinggi Corpus pada Level M1M2 & H at M2 CH, (Kaifu, 1997) \\
$\mathbf{4}$ & H M3 & Tinggi Corpus pada Level M2M3 & H at M69-2, (Martin and Saller, 1957) \\
$\mathbf{5}$ & T P4 & Tebal Corpus pada Level P4 & T at P4 CH, (Kaifu, 1997) \\
$\mathbf{6}$ & T M1 & Tebal Corpus pada Level M1M2 & T at M1-2 CH, (Kaifu, 1997) \\
$\mathbf{7}$ & T M2 & Tebal Corpus pada Level M1M2 & T at M1-2 CH, (Kaifu, 1997) \\
$\mathbf{8}$ & T M3 & Tebal Corpus pada Level M2M3 & T at M69-2, (Martin and Saller, 1957) \\
$\mathbf{9}$ & CL PM-M & Jarak Corpus antara PM-M & Cord length of $m_{2} p_{1}$, (Morant, 1923) \\
\hline
\end{tabular}

Keterangan: *Pengukuran dilakukan dalam satuan millimeter ( $\mathrm{mm})$

Selain itu juga digunakan dua variabel untuk studi morfometri gigi-geligi, yaitu:

- MD : pengukuran jarak maksimal mesial - distal pada posisi anatomis, dalam millimeter

- BL : pengukuran jarak maksimal buccal - lingual pada posisi anatomis, dalam millimeter

- $\quad \mathbf{C H} \quad$ : tinggi mahkota (estimasi) keseluruhan, dalam millimeter

\section{DESKRIPSI MORFOLOGI DAN MORFOMETRI}

Pada bulan Juni dan Agustus tahun 2014 ditemukan dua spesimen rahang yang sangat unik oleh Dakri, seorang warga lokal yang aktif dalam kegiatan pelestarian Situs Semedo. Temuan tersebut adalah dua spesimen mandibula yang oleh Balai Arkeologi Yogyakarta diberi identitas dengan nomor Semedo 3417 dan Semedo 3418. Kedua spesimen ditemukan di permukaan tanah, sehingga belum dapat ditelusuri konteks litostratigrafi aslinya. Namun, berdasarkan pada matriks yang tersisa dapat diketahui bahwa sedimen fosil ini ditemukan adalah pasir krikilan. Pada masa yang akan datang harus dilakukan penelitian mendalam guna mengetahui lapisan sedimen asli tempat fosil-fosil tersebut ditemukan.

Kondisi konservasi kedua spesimen sangat baik, namun terdapat jejak pecah-pecah pada bagian permukaannya. Proses fosilisasi sudah mencapai tingkat lanjut, sehingga komposisi mineral biotiknya telah berubah, bentuknya menjadi terlihat massif dan berat. Pada satu sisi lateral terdapat jejak warna kehitaman yang diidentifikasi sebagai mineral mangan, sehingga dapat diperkirakan bahwa fosil tersebut diendapkan pada lingkungan yang berair.

Kedua spesimen ini secara morfologis sangat mirip dengan bentuk rahang primata, namun berukuran sangat besar dibandingkan dengan ukuran mandibula primata besar yang umum dijumpai, seperti misalnya Orang Utan maupun Gorilla. Berikut ini adalah hasil studi morfologi dan metrik temuan kedua spesimen tersebut. 


\section{Spesimen Semedo 3417}

Spesimen yang pertama ditemukan adalah Semedo 3417. Spesimen ini ditemukan pada bulan Juni 2014 di sekitar area Brug Blendung pada Petak 33 lahan Perhutani. Materi tersisa dari spesimen 3417 secara umum dapat diidentifikasi sebagai fragmen mandibula sinistra (kiri) dengan gigigeligi molar. Pilar ramus mandibular dan condyle telah hilang, sehingga bagian sudut gonial tidak tampak. Di bagian lateral pada corpus mandibular terdapat oblique line yang cukup jelas, dan jejak perlekatan akar gigi yang tampak dari bagian distal $\mathrm{PM}_{4}$ sin sampai pada $\mathrm{M}_{3}$ sin, sehingga mengesankan bahwa individu tersebut bekerja keras dengan peralatan mastikasinya yang cukup kekar (Gambar 2). Berikut ini adalah hasil pengukuran pada mandibula spesimen 3417.

Tabel 2. Morfometri Mandibula Spesimen Semedo 3417, dalam millimeter (Sumber: Penulis)

\begin{tabular}{lcccc}
\hline Variabel & $\begin{array}{c}\mathrm{PM}_{4} \\
\operatorname{Sin}\end{array}$ & $\begin{array}{c}\mathrm{M}_{1} \\
\text { Sin }\end{array}$ & $\begin{array}{c}\mathrm{M}_{2} \\
\text { Sin }\end{array}$ & $\begin{array}{c}\mathrm{M}_{3} \\
\text { Sin }\end{array}$ \\
\hline $\begin{array}{l}\text { Tinggi } \\
\text { Corpus }\end{array}$ & $62.50^{*}$ & 64.75 & 67.78 & 74.50 \\
$\begin{array}{l}\text { Tebal } \\
\text { Corpus }\end{array}$ & 28.55 & 28.55 & 31.20 & 36.55 \\
$\begin{array}{l}\text { Jarak } \\
\text { Corpus } \\
\mathrm{P}_{4}-\mathrm{M}_{2}\end{array}$ & & & & \\
\hline
\end{tabular}

Keterangan: *terdapat bagian yang kurang lengkap

Gigi-geligi pada mandibula spesimen Semedo 3417 yang masih tersisa adalah fragmen Molar pertama, kedua dan ketiga yang relatif utuh (Gambar 2.). Berikut ini adalah deskripsi morfologi gigi-gigi tersebut:
$\mathrm{M}_{1}$ Sin : mahkota pecah, tidak tersisa sedikitpun. Hanya menyisakan dua baris akar gigi. Hanya menyisakan dentine dan root canal yang penampangnya berbentuk memanjang.

$\mathrm{M}_{2}$ Sin : hampir utuh, jejak karies ringan pada protoconid dan hypoconid namun tidak sampai menembus hingga pulp chamber, atrisi sedang pada seluruh permukaan cuspic, entoconid berukuran sedang, hypoconulid sangat berkembang.

$\mathrm{M}_{3}$ Sin : hampir utuh, jejak karies ringan pada protoconid namun tidak sampai menembus hingga pulp chamber, atrisi sedang pada seluruh permukaan cuspic, entoconid berukuran kecil, hypoconulid cukup berkembang.

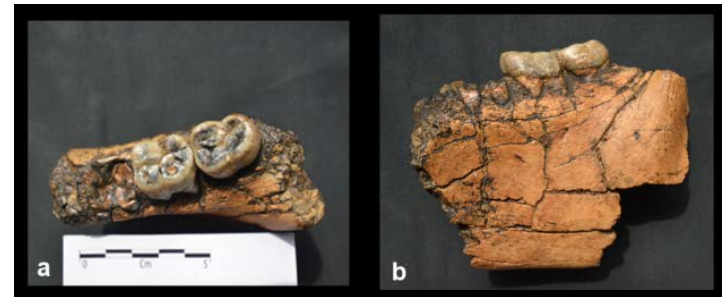

Gambar 2. Spesimen Semedo 3417 dari (a) sisi Occlusal dan (b) sisi Lateralis (Dok. Penulis).

Kemudian, di bawah ini adalah hasil pengukuran morfometri gigi-geligi spesimen 3417 dengan beberapa variable:

Tabel 3. Morfometri Gigi-geligi Spesimen Semedo 3417 dalam millimeter (Sumber: Penulis)

\begin{tabular}{lrr}
\hline Variabel & $\mathrm{M}_{2}$ Sin & $\mathrm{M}_{3}$ Sin \\
\hline $\mathrm{MD}$ & 20.50 & 21.25 \\
$\mathrm{BL}$ & 19.00 & 18.00 \\
$\mathrm{CH}$ & 9.50 & 9.00 \\
\hline
\end{tabular}




\section{Spesimen Spesimen 3418}

Fosil kedua yang ditemukan di Semedo adalah Semedo 3418. Spesimen ini ditemukan pada bulan Agustus 2014 di sekitar area Kalen Damad pada Petak 33 juga lahan Perhutani. Materi tersisa dari spesimen 3418 secara umum dapat diidentifikasi sebagai dua buah fragmen corpus mandibular sinistra (kiri) dan dextra (kanan) yang terkompresi menjadi satu. Corpus mandibular sinistra tertutup matriks, corpus kanan tidak utuh tingginya

Kedua fragmen corpus tersebut masih dilengkapi dengan gigi-gigi molar. Pilar ramus mandibular dan condyle pada kedua corpus telah hilang, sehingga bagian sudut gonial tidak tampak. Di bagian lateral pada corpus mandibular dextra terdapat oblique line yang cukup jelas, dan jejak perlekatan akar gigi yang tampak dari bagian distal $\mathrm{M}_{2}$ Dex sampai pada $\mathrm{M}_{3}$ Dex. Sedangkan pada permukaan bagian lateral corpus mandibular sinistra kondisinya agak sulit untuk diamati (Gambar 3.). Berikut ini adalah hasil pengukuran pada mandibula spesimen 3418.

Tabel 4. Morfometri Mandibula Spesimen Semedo 3418 dalam millimeter (Sumber: Penulis)

\begin{tabular}{lrrr}
\hline \multicolumn{1}{c}{ Variabel } & $\mathrm{M}_{3} \operatorname{Sin}$ & $\mathrm{M}_{2}$ Dex & $\mathrm{M}_{3}$ Dex \\
\hline $\begin{array}{l}\text { Tinggi } \\
\text { Corpus }\end{array}$ & 60.50 & $43.00^{*}$ & $43.00^{*}$ \\
Tebal Corpus & 28.00 & 28.00 & 29.50 \\
\hline
\end{tabular}

Keterangan: *terdapat bagian yang kurang lengkap

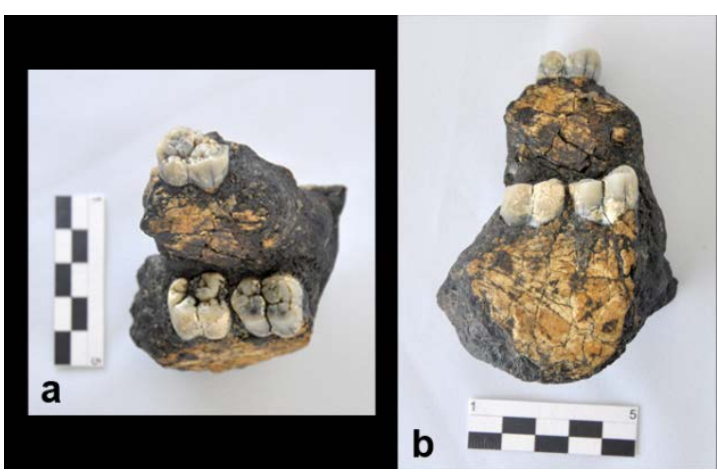

Gambar 3. Spesimen 3418 dari (a) sisi Occlusal dan (b) sisi Lateral Dextra (Dok. Penulis).

Gigi-geligi pada mandibula spesimen 3418 yang masih tersisa adalah fragmen Molar kedua pada corpus sinistra, Molar pertama dan Molar kedua yang relative utuh pada corpus dextra. Berikut ini adalah deskripsi morfologi gigi-gigi tersebut:

$\mathrm{M}_{3}$ Sin : Enamel kurang lengkap, cuspic pada sisi mesio lingual (protoconid) pecah. Terdapat sedikit atrisi pada bidang metaconid namun pola alur fissure masih tampak jelas. Entoconid berukuran relative kecil, sedangkan hypoconulid cukup berkembang. Terdapat kemungkinan jejak kalkulus (?) pada enamel.

$\mathrm{M}_{2}$ Dex: Bentuk enamel relatif utuh. Terdapat jejak kalkulus, sedikit atrisi pada bidang protoconid dan hypoconid. Entoconid berukuran kecil, sedangkan ukuran hypoconulid cukup berkembang.

$M_{3}$ Dex: Bentuk enamel relatif utuh. Kondisinya mirip dengan gigi sebelumnya. Terdapat jejak kalkulus, sedikit atrisi pada bidang protoconid dan hypoconid. Entoconid berukuran kecil, sedangkan ukuran hypoconulid cukup berkembang.

Kemudian, di bawah ini adalah hasil pengukuran morfometri 
gigi-geligi spesimen Semedo 3418 dengan beberapa variabel:

Tabel 5. Morfometri Gigi-geligi

Spesimen Semedo 3418 dalam millimeter (Sumber: Penulis)

\begin{tabular}{lrrr}
\hline Variabel & $M_{3} \sin$ & $M_{2}$ Dex & $M_{3}$ Dex \\
\hline $\mathrm{MD}$ & 18.50 & 19.00 & 18.30 \\
$\mathrm{BL}$ & 15.50 & $15.50^{\star}$ & $16.00^{\star}$ \\
$\mathrm{CH}$ & 10.40 & 14.00 & 13.35 \\
\hline
\end{tabular}

Keterangan: *terdapat bagian yang sulit diukur

Berbeda dengan spesimen sebelumnya, Semedo 3418 nampaknya merupakan individu muda. Hal ini nampak pada jejak atrisi pada sisi occlusal Molar ketiga yang sangat sedikit, atau bahkan hampir belum membekas.

\section{KAJIAN MORFOLOGI DAN MORFOMETRI PRIMATA BESAR DARI SEMEDO}

$$
\text { Dalam bioantropologi }
$$

tradisional terdapat dua set metode analisis, yaitu; non-metric (kualitatif) dan metric (kuantitatif). Aplikasi metode tersebut biasanya berguna untuk mengidentifikasi identitas fosilfosil purba (Larsen dan Walker, 2010). Metode kualitatif juga dikenal sebagai analisis morfologi, sedangkan metode kuantitatif disebut sebagai "traditional" morphometric (Marcus, 1990). Metode terakhir tersebut juga melibatkan teknik analisis statistik multivariabel, atau dikenal sebagai "multivariate morphometrics" (Slice, 2006).

\section{Studi Komparasi Morfologi}

Spesimen pembanding yang dilakukan dalam studi komparasi morfologi untuk mengidentifikasi identitas spesimen Semedo 3417 dan 3418 adalah holotype fosil
Gigantopithecus blacki atau disebut sebagai "spesimen 1" dalam koleksi von Koenigswald, yang kini tersimpan di SenckenbergNaturmuseum, Frankfurt am Main, Jerman dan deskripsinya telah diterbitkan oleh von Konigswald (1953) (Gambar 4.).
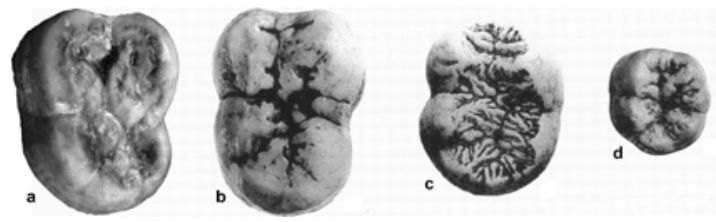

Gambar 4. (a) Gigantopithecus dari Semedo, (b) Gigantopithecus blacki, (c) Pongo pigmaeus, (d) Homo sapiens.

(Sumber: von Koenigswald, 1953 kecuali (a) Dok. Penulis)

Secara umum, pola fissure yang membatasi cuspic pada bidang occlusal Molar di kedua spesimen dari Semedo adalah berbetuk pola "Y-5 Molar". Pola ini pada umumnya dimiliki oleh superfamily Hominoidea, sedangkan bentuk pola Bilophodont Molar biasanya dimiliki oleh Cercopithecoidea (Nail, 1998). Superfamily Hominoidea terdiri atas family; Hominidae (Homo dan Australopithecines), Hylobatidae (Gibon), Pongidae (Gorilla, Pongo, dan Pan).

Molar Gigantopithecus memiliki lima cuspic utama, dengan bidang metaconid merupakan bagian yang paling luas di sisi antero-lingual. Metaconid ini memiliki kontak langsung dengan bidang hypoconid yang terletak di sisi postero-labial dan dipisahkan dengan sebuah fissure yang jelas. Di sisi antero-labial terdapat bidang protoconid yang juga dipisahkan dengan celah yang jelas. Selain itu juga terdapat "deflecting wringkle" pada bidang metacone. Karakter ini sangat berkembang pada kelompok Hominid, karena kemungkinan 
merupakan karakter primitif akibat evolusi dari puncak trigonid.

$\begin{array}{lrr} & \text { Selain itu juga } & \text { terdapat } \\ \text { fissure pada bidang } & \text { medial } \\ \text { permukaan occlusal yang }\end{array}$
memanjang ke arah anterior hingga ke bagian enamel inferior, sedangkan fissure yang ke arah posterior tidak terlalu panjang. Bidang hypoconid berukuran lebih besar dari pada bidang entoconid yang berada di sisi postero-lingual. Hal ini mungkin disebabkan oleh karena hypoconid mengekspansi ruang entoconid, dan karakter ini biasanya terdapat pada Gorilla dan Orangutan.

Di bagian medial batas anterior terdapat single cuspic yang berukuran kecil, karakter ini mirip dengan yang biasanya terdapat dalam kelompok Hominid. Di batas antara bidang protoconid di sisi antero-labial dan bidang entoconid di sisi postero-lingual, terdapat "tuberculum accessorium mediale internum". Pada Molar juga terdapat tuberculum sextum yang berbentuk segitiga kecil dan terletak di antara entoconid dan hypoconulid. Cuspic tambahan di antara protoconid dan entoconid, serta tuberculum tersebut biasanya sangat sering dijumpai pada semua kelompok Anthropoid. Selain itu juga terdapat cuspic tambahan pada batas anterior bidang entoconid.

Pola fissure dan cuspic pada Molar Spesimen 1 (von Koenigswald), Semedo 3417 dan Semedo 3418 memiliki banyak kesamaan. Sehingga diduga kuat bahwa kedua spesimen dari Semedo tersebut termasuk dalam kelompok Gigantopithecus, walaupun masih problematik.

\section{Studi Komparasi Morfometri}

Untuk melengkapi studi komparasi morfologi di atas, maka selanjutnya dilakukan studi morfometri. Berdasarkan hasil pengukuran diketahui bahwa ukuran gigi spesimen Semedo khususnya Semedo 3417, mirip dengan sampel Orangutan dan Gorilla terbesar yang merupakan anggota Pongidae yaitu sekitar 18-22 $\mathrm{mm}$ (Simons dan Chopra, 1969). Spesimen Semedo memiliki karakter khusus dengan bidang trogonid yang lebih luas dari pada bidang talonid, sehingga memiliki index trigonid yang rendah dan ini biasanya dimiliki oleh kelompok Hominid.

bahwa tinggi metaconid gigi Spesimen Semedo yaitu antara 9 $14 \mathrm{~mm}$ sehingga mirip dengan Gigantopithecus dan berbeda dengan sampel Gorilla yang hanya hanya $8.5 \mathrm{~mm}$ (lihat von Koenigswald, 1935). Sehingga studi komparasi morfometri terhadap spesimen Semedo ini akan dilakukan dengan melibatkan Gigantopithecus dan anggota kelompok Hominidae, yaitu; Australopithecus, Paranthropus, dan Homo erectus. Berikut ini adalah hasil analisis tersebut:

\section{a. Analisis Univariate dan Bivariate}

Komparasi morfometri pertama yang digunakan adalah analisis satu variabel (univariate). Analisis ini digunakan hanya untuk satu variabel independen, yang dalam penelitian ini adalah jarak corpus dari Premolar ke Molar sesuai dengan metode yang digunakan oleh Morant (1923). Hasilnya adalah spesimen Semedo 3417 yang berukuran $50.70 \mathrm{~mm}$ 
berada di dalam 25th percentile (Q1) pada interquartile range populasi Gigantopithecus, namun juga berada pada range nilai maksimum (Max) populasi Australopithecines robust (Paranthropus) (lihat Gambar 5., kiri).

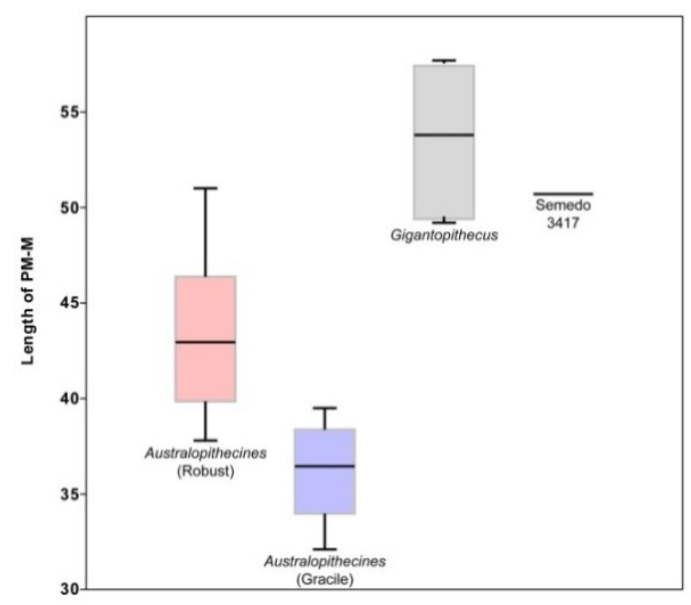

robust (Paranthropus) (Gambar 5., kanan).

Analisis bivariate selanjutnya dilakukan untuk mengetahui hubungan antara panjang MesioDistal (MD) dan lebar Bucco-Lingual (BL) gigi-geligi baik Molar kedua maupun ketiga. Pada MD versus BL

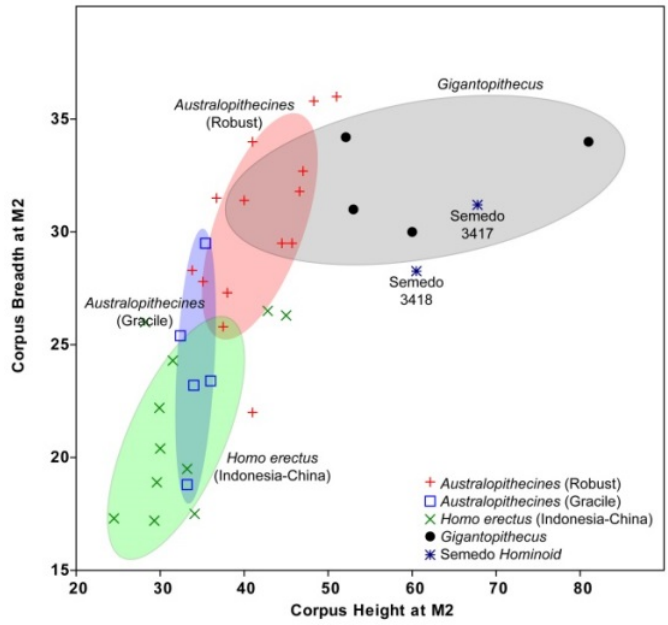

Gambar 5. Analisis Univariate CL PM-M (kiri) dan Analisis Bivariate H M2 vs T M2 (kanan) (Sumber: Penulis)

Studi komparasi selanjutnya dilakukan dengan analisis bivariate yang bertujuan untuk mengkaji hubungan antara dua variable yang telah diukur. Setiap plot koordinat menunjukan skor $X$ dan $Y$ dari satu individu yang sama, sedangkan bidang elips menunjukan 60\% variasi dari sebuah populasi.

Analisis Bivariate pertama dilakukan untuk mengetahui hubungan antara tinggi dan tebal corpus pada gigi Molar (H M2 vs $\mathrm{T}$ M2) seperti yang disarankan oleh Kaifu (1997). Hasilnya adalah kedua spesimen Semedo 3417 dan Semedo 3418 berada dalam populasi Gigantopithecus dalam hal tinggi corpus. Namun demikian, keduanya dan juga termasuk semua individu populasi Gigantopithecus memiliki tebal corpus yang sama dengan populasi Australopithecines
M2 diketahui bahwa spesimen Semedo 3417 memiliki korelasi ukuran M2 yang jauh lebih besar di atas populasi Australopithecines robus dan graciles serta Homo erecus dari Jawa dan China. Kemudian spesimen Semedo 3418 memiliki ukuran M2 yang agak mirip dengan Australopithecines khususnya populasi robust pada variabel lebar Bucco-Lingual (lihat Gambar 6., kiri). Namun demikian harus hati-hati, karena kemungkinan spesimen Semedo 3418 adalah individu muda, sehingga ukuran pertumbuhan gigi-geliginya belum maksimal.

Pada MD versus BL M3 diketahui bahwa spesimen Semedo 3417 memiliki korelasi ukuran M3 yang sangat mirip dengan populasi Gigantopithecus dan jauh lebih besar dari pada populasi Hominid 
lainnya, walaupun juga terdapat dua individu Paranthropus yang memiliki korelasi ukuran mirip dengan populasi Gigantopithecus tersebut. Karena kita memiliki sampel M3 dari spesimen Semedo 3418 yang kemungkinan berumur muda sehingga pertumbuhannya belum sempurna, maka harus berhati-hati dalam mengkaji dan membandingkannya dengan populasi lain (Gambar 6., kanan).

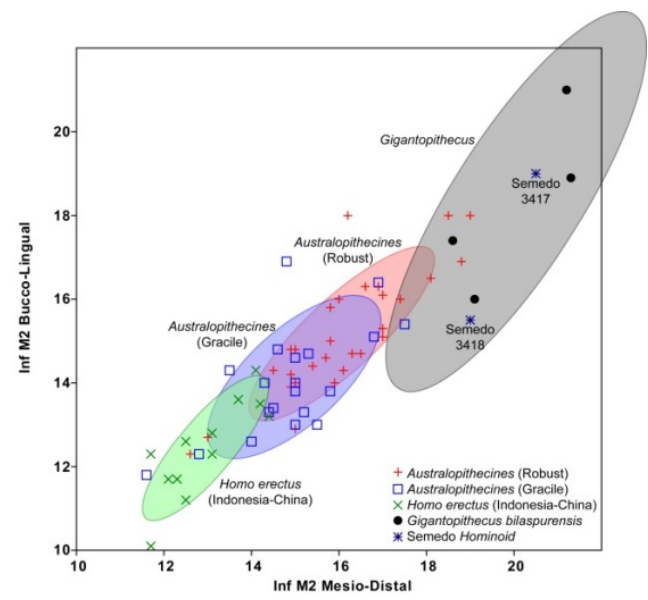

Berdasarkan hasil analisis klaster terhadap sampel-sampel yang diukur dalam penelitian ini, maka dapat diketahui bahwa terdapat dua cabang utama populasi Superfamily Hominoid, yang terdiri dari Hominoid berukuran besar (Giogantopithecus) dan Hominoid berukuran kecil (Hominid). Kedua spesimen Semedo 3417 dan Semedo 3418 berada di dalam satu kelompok bersama empat spesimen Gigantopithecus dan dua spesimen dari East-Rudolf.

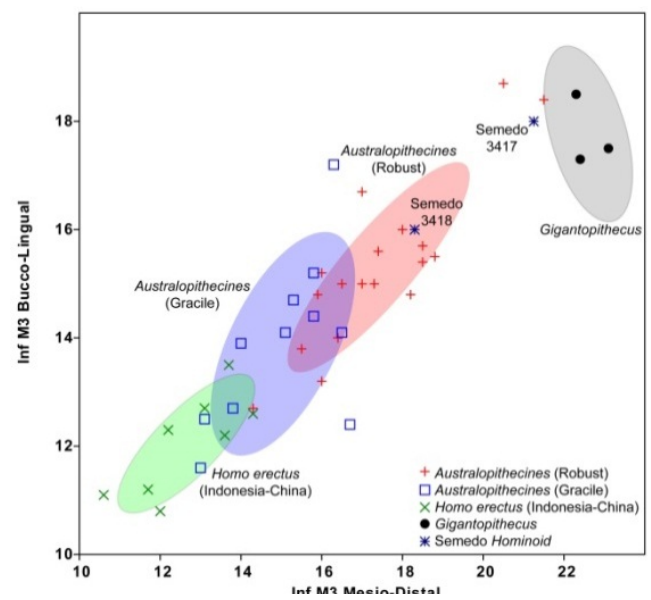

Gambar 6. Analisis Bivariate MD vs BL pada M2 (kiri) dan MD vs BL pada M3 (kanan)

(Sumber: Penulis)

\section{b. Analisis Klaster}

Setelah analisis univariate dan bivariate, kemudian digunakan analisis klaster (cluster analysis) yang merupakan salah satu metode dalam analisis multi variabel (multivariate analysis). Metode yang digunakan adalah ward's method yang mengukur jarak kemiripan dengan metode Euclidean Distance terhadap data mentah (raw data) pada hasil pengukuran beberapa variabel morfometri. Metode ini sangat berguna untuk merangkum probabilitas utama dalam menentukan klaster populasi (Gambar 7.).
Selanjutnya, pada kluster Hominoid berukuran kecil terdapat dua cabang besar yang terdiri dari kelompok Homo erectus (Jawa dan China), serta Australopithecines yang terdiri dari cabang Australopithecus (gracile) dan Paranthropus (robust). Menarik bahwa mandibula Sangiran 6 (Meganthropus A) dan Sangiran 8 (Meganthropus $B$ ) yang selama ini posisi taksonominya masih problematik, berada pada populasi Paranthropus. 


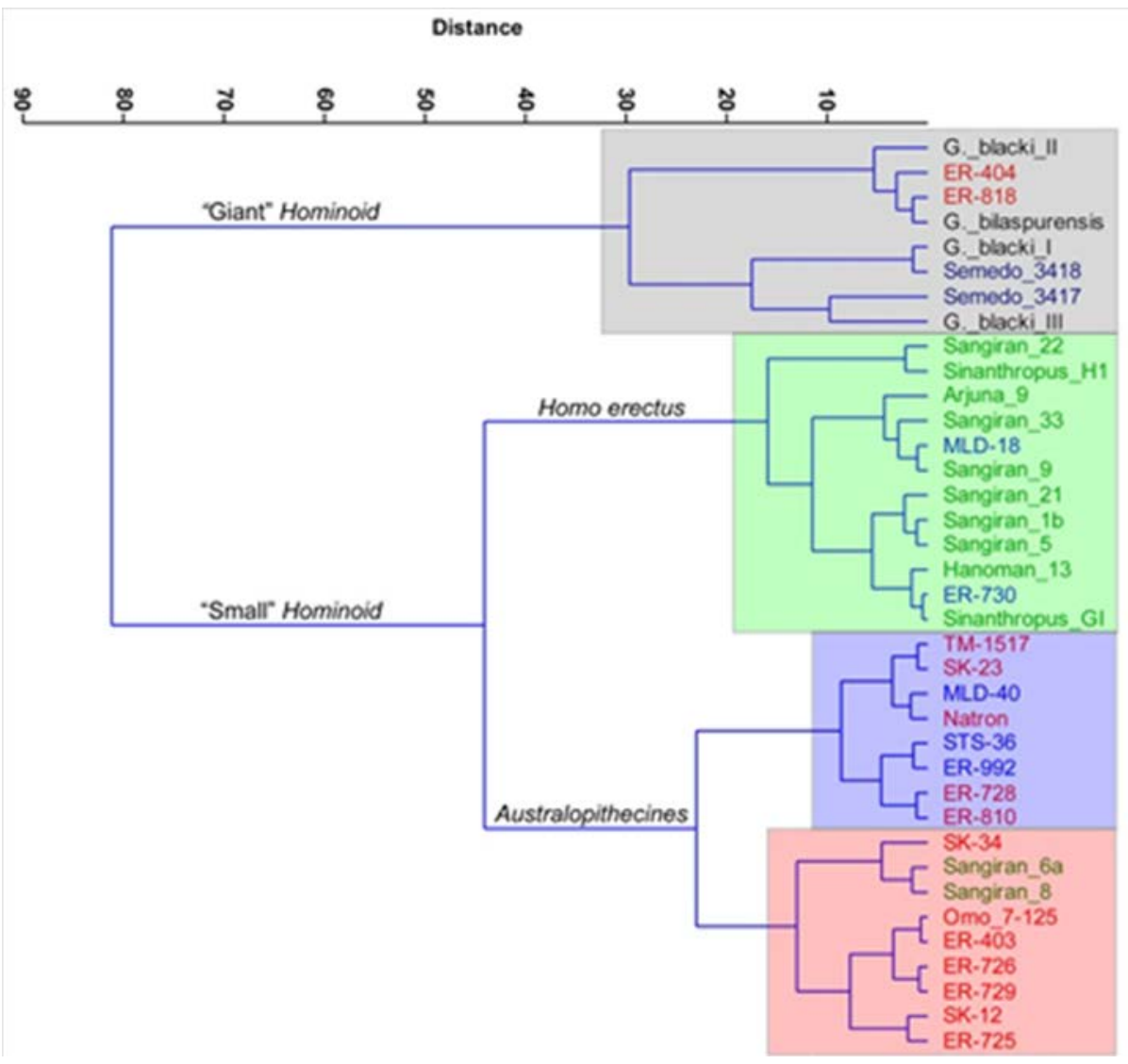

Gambar 7. Analsis Klaster Spesimen Semedo berdasarkan Morfometri mandibular (Sumber: Penulis)

\section{POSISI TAKSONOMI \\ GIGANTOPITHECUS DARI SEMEDO}

Berdasarkan hasil analisis dalam penelitian ini, maka dapat diketahui posisi taxonomi primata besar dari Semedo. Spesimen Semedo 3417 bedasarkan eksplorasi karakter morfologi dan morfometri pada mandibula dan gigi cenderung dekat dengan populasi Gigantopithecus blacki. Kemudian, spesimen Semedo 3418 bedasarkan pada karakter morfologi gigi dan morfometri mandibula cenderung dekat dengan populasi Gigantopithecus, sedangkan karakter morfometri gigi-geliginya cenderung lebih kecil dari pada spesimen Semedo 3417 dan populasi Gigantopithecus. Ada kemungkinan spesimen Semedo 3418 termasuk dalam populasi Australopithecines (robust) atau Paranthropus berdasarkan morfometri giginya.

Gigantopithecus merupakan nama yang pertama kali diajukan von Koenigswald (1935) berdasarkan temuan Molar berukuran sangat besar yang didapat dari sebuah toko obat di Hong Kong yang menjual "Gigi Naga". Berdasarkan pada bentuk morfologi occlusal molar tersebut, Weidenreich (1946) memposisikan 
Gigantopithecus dalam garis family Hominidae. Menurutnya, gigantism merupakan karakter arkaik pada kera dari pada dwarfism, sehingga evolusi manusia modern seharusnya berasal dari Gigantopithecus, kemudian Meganthropus, melalui Pithecanthropus, dan akhirnya Homo sapiens.

Pada awalnya von Koenigswald, beranggapan bahwa Gigantopithecus merupakan anggota Hominid. Tapi kemudian dia menyadari bahwa karakter dan ukuran gigi-geliginya terlalu spesifik dan besar untuk dimasukan dalam garis Homo. Dia mengubah pendapatnya bahwa Gigantopithecus termasuk dalam superfamily Hominoidae. Von Koenigswald (1983) menyatakan bahwa mahluk tersebut memiliki hubungan dengan Ramapithecus dan Sivapithecus.

Pilbeam (1970) berdasarkan karakter mandibula menyarankan bahwa Gigantopithecus dan Dryopithecus seharusnya ditempatkan dalam famili Pongidea bersama dengan kera besar lainnya, yaitu; Orangutan, Simpanse, dan Gorilla. Sependapat dengan Pilbeam adalah Martin (1990). Robinson dan Staudel (1973) berdasarkan analisis pola gigi menyarankan bahwa tempat Gigantopithecus adalah diantara Pongidae dan Hominidae, khususnya lebih dekat dengan kelompok Paranthropus. Karena sifatnya yang sangat problematis, maka hingga saat ini para peneliti belum sepakat mengenai tempat yang tepat bagi Gigantopithecus dalam taksonomi primata.

\section{Penemuan} spesimen Gigantopithecus di Situs Semedo dalam penelitian ini merupakan yang pertama kali di wilayah Indonesia, maupun di kawasan tropis pada umumnya. Sebelumnya, di belahan dunia lama paling tidak telah ditemukan dua spesies Gigantopithecus yang terdiri dari (Pope dan Delson, 2000);

- Gigantopithecus blacki (von Koenigswald) dari China selatan dan Vietnam utara

- Gigantopithecus bilaspurensis (G. giganteus) dari IndoPakistan utara

Rentang waktu keberadaan Gigantopithecus berdasarkan fosilfosil yang telah ditemukan adalah antara Miosen Akhir hingga Plestosen Tengah. Spesies yang pertama muncul adalah Gigantopithecus bilaspurensis atau Gigantopithecus giganteus pada sekitar 7.5 juta tahun yang lalu di pegunungan Siwalik, Indo-Pakistan. Kemudian spesies Gigantopithecus blacki ditemukan di China selatan dan Vietnam utara dalam rentang waktu 2-0.3 juta tahun yang lalu (Grehan and Shwartz, 2009). Di Vietnam utara pada 0.4 juta tahun yang lalu terdapat bukti bahwa Gigantopithecus hidup berdampingan dengan Homo erectus (Pope dan Delson, 2000). Hal yang mirip kemungkinan juga terjadi di Jawa, walaupun masih perlu pengumpulan bukti yang lebih banyak lagi.

\section{PENUTUP}

Penelitian ini telah berhasil mengungkap identitas dan posisi taksonomi dari spesimen Semedo 3417 dan Semedo 3418. Hasil analisis morfologi dan morfometri menunjukan bahwa spesimen tersebut merupakan anggota dari Gigantopithecus, khususnya lebih dekat pada spesies G. blacki. Penelitian ini membuka berbagai permasalahan penelitian 
selanjutnya, seperti misalnya; kapankah mereka mulai mengkoloni Pulau Jawa?, bagaimanakah pola diet dan adaptasi mereka di lingkungan tropis?, apakah mereka hidup berdampingan dengan Homo erectus?, kemudian bagaimanakah pada akhirnya mereka punah?. Semoga di masa yang akan datang muncul bukti dan teknik analisis terbaru guna mengungkap berbagai permasalahan tersebut.

Selian itu, penemuan Gigantopithecus ini juga menambah keragaman fosil primata yang ditemukan di Situs Semedo, setelah sebelumnya pada tahun 2011 telah ditemukan fragmen atap tengkorak Homo erectus "Semedo 1". Pada perspektif Pulau Jawa dan Kepulauan Indonesia pada umumnya, penemuan Gigantopithecus menambah panjang catatan keragaman fosil dikawasan ini, setelah sebelumnya ditemukan Homo soloensis, dan Homo floresiensis. Hal ini membuktikan bahwa wilayah topis memiliki tingkat keragaman hayati yang tinggi tidak hanya pada saat ini, namun juga (berevolusi) sejak jutaan tahun yang lampau.

\section{UCAPAN TERIMA KASIH}

Ucapan Terima kasih disampaikan kepada Dr. Christine Hertler dan Dr. Friedemann Schrenk, kurator Koenigswald's Collection pada Senckenberg-Naturmuseum, Frankfurt am Main atas diskusi dan kesempatan yang diberikan kepada penulis untuk mempelajari secara langsung fossil Gigantopithecus blacki (Koenigswald).

Terima kasih atas kerjasama seluruh anggota tim Balai Arkeologi Yogyakarta yang terlibat dalam Penelitian Manusia, Budaya, dan
Lingkungan pada Kala Plestosen di Situs Semedo, Kabupaten Tegal, Jawa Tengah. Khususnya kepada alm. Rokhus Due Awe "Sang Pemulung Tua", seorang guru, sahabat, orang tua, dan anggota tim yang terlihat dalam penelitian ini.

Terima $\begin{gathered}\text { kasih } \\ \text { kepada }\end{gathered} \begin{gathered}\text { juga } \\ \text { Dinas }\end{gathered}$
Kebudayanan dan Pariwisata Kab.
Tegal, masyarakat Desa Semedo,
Kecamatan Kedungbanteng,
khususnya yang berperan aktif pada
pelestarian Situs Semedo; Dakri,
Duman, dan Sunardi.

Penulis juga mengucapkan terima kasih kepada Prof. Dr. Yahdi Zaim, mitra bestari Jurnal Berkala Arkeologi yang telah memeriksa, mengoreksi, dan memberi masukan membangun untuk perbaikan tulisan ini. 


\section{DAFTAR PUSTAKA}

Bulbeck, D dan S. O'Connor. 2011. "The Watinglo mandible: A second terminal Pleistocene Homo sapiens fossil from tropical Sahul with a test on existing models for the human settlement of the region", HOMO - Journal of Comparative Human Biology 62. pp. 1-29

Frayer, David W. 1975. "Gigantopithecus and its relationship to Australopithecus", American Journal of Physical Anthropology 39/3, pp. 413-426

Grehan, J.R. dan J.H. Schwartz. 2009. "Evolution of the Second Orangutan: Phylogeny and Biogeography of Hominid Origins", Journal of Biogeography 36, pp. 1823-1844

Howell, F. C. 1969. "Remains of Hominidae from Pliocene/Pleistocene formations in the lower Omo basin, Ethopia", Nature 223, pp. 1234-1239.

Kaifu, Y. 1997. "Changes in Mandibular Morphology from the Jomon to Modern Periods in Eastern Japan", American Journal of Physical Anthropology 104. pp. 227-243

Larsen, C. S. dan Phillip L. Walker. 2010. "Bioarchaeology: Health, Lifestyle, and Society in Recent Human Evolution", in Clark Spencer Larsen ed., A Companion to Biological Anthropology. Singapore: Blackwell Publishing. pp. 379-394.

Marcus, L. F. 1990. "Chapter 4. Traditional morphometrics", dalam F. J. Rohlf and F. L. Bookstein. (eds) Proceedings of the Michigan Morphometric Workshop, Special Publication No. 2, Ann Arbor MI: The University of Michigan Museum of Zoology, pp. 77-122.

Martin R, dan Saller K. 1957. Lehrbuch der Antropologie. Stuttgart: Gustav Fischer Verlag.

Martin R.D. 1990. Primate Origins and Evolution: A phylogenetic reconstruction, New Jersey: Princeton University Press.

Morant, G.M., 1923. "A first study of the Tibetan skull". Biometrika 14, pp. 193260.

Nail, K. 1998. "The mysterious phylogeny of gigantopithecus", Lambda Alpha Journal, Vol. 28, pp. 28-36.

Noerwidi, S. dan Siswanto. 2014. "Alat Batu Situs Semedo: Keragaman Tipology dan Distribusi Spasialnya", Berkala Arkeologi Vol.34 No.1, Yogyakarta: Balai Arkeologi Yogyakarta

Pilbeam, D. 1970. "Gigantopithecus and the origins of Hominidae", Nature 225, pp. 516-519.

Pope, G.G. dan E. Delson. 2000. "Gigantopithecus", dalam E. Delson, I. Tatersal, J.A. van Couvering, A.S. Brooks (eds): Encyclopedia of Human Evolution and Prehistory, 2nd edition, New York: Garlan, pp. 288-289. 
Simons, E.L. dan S.R.K Chopra. 1969. "Gigantopithecus (Pongidae, Hominoidea): a New Species from North India". Postilla (138), pp. 1-18.

Siswanto. 2013. "Penelitian Manusia, Budaya, dan Lingkungan pada Kala Plestosen di Situs Semedo, Kabupaten Tegal, Jawa Tengah", Laporan Penelitian Arkeologi, Yogyakarta: Balai Arkeologi

Siswanto. 2014. "Penelitian Manusia, Budaya, dan Lingkungan pada Kala Plestosen di Situs Semedo, Kabupaten Tegal, Jawa Tengah", Laporan Penelitian Arkeologi, Yogyakarta: Balai Arkeologi

Siswanto dan Noerwidi, Sofwan. 2014. "Fosil Proboscidea dari Situs Semedo: Hubungannya dengan Biostratigrafi dan Kehadiran Manusia di Jawa", Berkala Arkeologi Vol.34 No.2, Yogyakarta: Balai Arkeologi Yogyakarta

Slice Dennis E. 2005. "Modern Morphometrics", in Dennis E. Slice (ed.), Modern morphometrics in physical anthropology, New York: Kluwer Accademic I Plenum Publishers, pp. 1-46.

Robinson, Jt dan Steudel, K. 1973. "Multivariate discriminant analysis of dental bearing on early hominid affmities", Journal of Human Evolution 2, pp. 509-527.

von Koenigswald, G.H.R. 1935. "Eine fossile saogetierfauna mit Simia aus Sudchina", Proc. K. Akad Wetensch, 38, Amsterdam, pp. 872-879.

1952. "Gigantopithecus blacki von Koenigswald, a giant fossil hominoid from the Pleistocene of Southern China", Anthro. Papers of Am. Mus. of Natl. Hist., 43, pp. 291-325.

1983. "The Significance of Hitherto Undescribed Miocene Hominoids fonn the Siwaliks of Pakistan in the Senckenberg Museum, Frankfurt", dalam RL Ciochon dan RS Corruceini (eds): New Interpretations of Ape and Human Ancestry, New York: Plenum Press, pp.539-557.

Weidenreich, F. 1945. "Giant early man from Java and south China", Anthro. Papers of Am. Mus. of Natl. Hist., 40, pp. 1-134. Chicago

1946. Apes, Giants, and Man. University of Chicago Press,

White, T.D., dan Folkens, P.A. 2005. The Human Bone Manual. London: Elsevier Academic Press.

Widianto, H. 1993. "Unité et diversité des hominidés fossiles de Java: Présentation de Restes Humains Fossiles Inédits", Thése du Docteural, Paris: MNHN.

2011. Nafas Sangiran, Nafas SItus-situs Hominid, Sragen: BPSMP Sangiran

Widianto, H., M. Hidayat. 2006. "Semedo, Situs Baru Kehidupan Manusia Purba pada Kala Plestosen", Berita Penelitian Arkeologi No. 21, Yogyakarta: Balai Arkeologi

Widiyanta, W., M. Hidayat. 2012. "Penelitian Homo erectus SItus Semedo: Umur, Budaya dan Lingkungan", Laporan Eksplorasi, Sragen: BPSMP Sangiran 


\section{Lampiran}

Material Komparasi: Pengukuran Mandibula dalam millimeter

\begin{tabular}{|c|c|c|c|c|}
\hline Spesimen & $\begin{array}{c}\text { Tinggi } \\
\text { Corpus } \mathrm{M}_{2}\end{array}$ & $\begin{array}{c}\text { Lebar } \\
\text { Corpus } \mathrm{M}_{2}\end{array}$ & Panjang $P_{4}-M_{2}$ & Referensi \\
\hline \multicolumn{5}{|c|}{ Australopithecines (Robust) } \\
\hline TM-1517 & 33.8 & 28.3 & 39.4 & Frayer, 1973 \\
\hline SK-12 & 41.0 & 34.0 & 40.0 & Frayer, 1973 \\
\hline SK-23 & 35.1 & 27.8 & 39.4 & Frayer, 1973 \\
\hline SK-34 & 41.0 & 22.0 & 43.1 & Frayer, 1973 \\
\hline SK-74 & & & 37.8 & Frayer, 1973 \\
\hline SK-858 & & & 40.7 & Frayer, 1973 \\
\hline Omo 7-125 & 47.0 & 32.7 & 44.7 & Frayer, 1973 \\
\hline ER-403 & 46.6 & 31.8 & 42.8 & Frayer, 1973 \\
\hline ER-404 & 48.3 & 35.8 & & Frayer, 1973 \\
\hline ER-725 & 40.0 & 31.4 & 42.5 & Frayer, 1973 \\
\hline ER-726 & 44.5 & 29.5 & 51.0 & Frayer, 1973 \\
\hline ER-728 & 37.5 & 25.8 & & Frayer, 1973 \\
\hline ER-729 & 45.7 & 29.5 & 47.5 & Frayer, 1973 \\
\hline ER-810 & 38.0 & 27.3 & 44.0 & Frayer, 1973 \\
\hline ER-818 & 51.0 & 36.0 & 50.8 & Frayer, 1973 \\
\hline Natron & 36.7 & 31.5 & 46.0 & Frayer, 1973 \\
\hline \multicolumn{5}{|c|}{ Australopithecines (Gracile) } \\
\hline MLD-18 & 32.4 & 25.4 & 35.4 & Frayer, 1973 \\
\hline MLD-40 & 35.4 & 29.5 & 38.0 & Frayer, 1973 \\
\hline STS-7 & 36.0 & & 37.5 & Frayer, 1973 \\
\hline STS-36 & 36.0 & 23.4 & & Frayer, 1973 \\
\hline STS-52 & & & 39.5 & Frayer, 1973 \\
\hline ER-730 & 33.2 & 18.8 & 32.1 & Frayer, 1973 \\
\hline ER-992 & 34.0 & 23.2 & 34.6 & Frayer, 1973 \\
\hline \multicolumn{5}{|c|}{ Homo erectus } \\
\hline Sangiran $1 \mathrm{~b}$ & 29.6 & 18.9 & & Widianto, 1993 \\
\hline Sangiran 5 & 30.0 & 20.4 & & Widianto, 1993 \\
\hline Sangiran $6 a$ & 45.0 & 26.3 & & Weidenreich, 1945 \\
\hline Sangiran $6 b$ & & 27.0 & & Widianto, 1993 \\
\hline Sangiran 8 & 42.8 & 26.5 & & Widianto, 1993 \\
\hline Sangiran 9 & 31.5 & 24.3 & & Widianto, 1993 \\
\hline Sangiran 21 & 29.3 & 17.2 & & Widianto, 1993 \\
\hline Sangiran 22 & 24.5 & 17.3 & & Widianto, 1993 \\
\hline Sangiran 33 & 29.9 & 22.2 & & Widianto, 1993 \\
\hline Sangiran 37 & & 17.6 & & Widianto, 1993 \\
\hline Arjuna 9 & 28.2 & 26 & & Widianto, 1993 \\
\hline Hanoman 13 & 34.1 & 17.5 & & Widianto, 1993 \\
\hline Sinanthropus GI & 33.2 & 19.5 & & Widianto, 1993 \\
\hline Sinanthropus H1 & 24.8 & 14.2 & & Widianto, 1993 \\
\hline \multicolumn{5}{|c|}{ Gigantopithecus } \\
\hline G. blacki I & 60.0 & 30.0 & 50.5 & Frayer, 1973 \\
\hline G. blacki II & 53.0 & 31.0 & 57.7 & Frayer, 1973 \\
\hline G. blacki III & 81.0 & 34.0 & 57.1 & Frayer, 1973 \\
\hline G. bilaspurensis & 52.1 & 34.2 & 49.2 & Frayer, 1973 \\
\hline
\end{tabular}


Material Komparasi: Pengukuran Gigi-geligi pada Australopithecines (Robust) dalam millimeter

\begin{tabular}{|c|c|c|c|c|c|c|c|c|c|c|}
\hline \multirow[t]{2}{*}{ Spesimen } & \multicolumn{3}{|c|}{$M_{1}$} & \multicolumn{3}{|c|}{$M_{2}$} & \multicolumn{3}{|c|}{$M_{3}$} & \multirow[t]{2}{*}{ Referensi } \\
\hline & M-D & B-L & $\mathbf{H}$ & M-D & B-L & $\mathbf{H}$ & M-D & B-L & $\mathrm{H}$ & \\
\hline Omo L7-125 & 16.8 & 18.7 & & 16.2 & 18.0 & & 18.2 & 14.8 & & Howell, 1969 \\
\hline Natron & 15.4 & 15.3 & & 17.0 & 16.1 & & 18.0 & 16.0 & & Frayer, 1973 \\
\hline TM-1517 & 13.8 & 13.2 & & 15.4 & 14.4 & & 16.4 & 14.0 & & Frayer, 1973 \\
\hline TM-1536 & 12.5 & 11.8 & & & & & & & & Frayer, 1973 \\
\hline TM-1600 & & & & 15.0 & 14.8 & & 15.9 & 14.8 & & Frayer, 1973 \\
\hline SK-1 & & & & 17.0 & 15.3 & & & & & Frayer, 1973 \\
\hline SK-5 & & & & 14.9 & 14.2 & & & & & Frayer, 1973 \\
\hline SK-6 & 15.9 & 15.4 & & 16.9 & 16.3 & & 18.5 & 15.4 & & Frayer, 1973 \\
\hline SK-12 & 15.0 & 14.4 & & 15.8 & 15.8 & & 16.0 & 15.2 & & Frayer, 1973 \\
\hline SK-15 & 12.0 & 12.0 & & 13.0 & 12.7 & & 14.3 & 12.7 & & Frayer, 1973 \\
\hline SK-20 & 14.7 & 14.2 & & & & & & & & Frayer, 1973 \\
\hline SK-23 & 14.5 & 14.6 & & 14.9 & 14.8 & & 16.0 & 13.2 & & Frayer, 1973 \\
\hline SK-25 & 14.7 & 14.0 & & 16.3 & 14.7 & & & & & Frayer, 1973 \\
\hline SK-34 & 13.5 & 14.5 & & 16.6 & 16.3 & & 17.0 & 16.7 & & Frayer, 1973 \\
\hline SK-37 & & & & 16.5 & 14.7 & & & & & Frayer, 1973 \\
\hline SK-45 & 11.3 & & & 12.6 & 12.3 & & & & & Frayer, 1973 \\
\hline SK-55 & 14.6 & 13.7 & & 16.1 & 14.3 & & 15.5 & 13.8 & & Frayer, 1973 \\
\hline SK-61 & 15.0 & 14.0 & & & & & & & & Frayer, 1973 \\
\hline SK-63 & 13.7 & 13.5 & & & & & & & & Frayer, 1973 \\
\hline SK-74 & 13.2 & 13.5 & & 14.5 & 14.3 & & & & & Frayer, 1973 \\
\hline SK-81 & 14.3 & 15.8 & & 16.0 & 16.0 & & 17.0 & 15.0 & & Frayer, 1973 \\
\hline SK-104 & & & & 14.9 & 13.9 & & & & & Frayer, 1973 \\
\hline SK-828 & 15.4 & 14.2 & & & & & & & & Frayer, 1973 \\
\hline SK-838b & 14.1 & 13.0 & & & & & & & & Frayer, 1973 \\
\hline SK-843 & 14.4 & 13.4 & & 15.9 & 14.0 & & 17.3 & 15.0 & & Frayer, 1973 \\
\hline SK-846a & 14.6 & 13.7 & & & & & & & & Frayer, 1973 \\
\hline SK-858 & 13.9 & 15.0 & & 15.8 & 15.0 & & & & & Frayer, 1973 \\
\hline SK-876 & 13.0 & 15.1 & & 17.0 & 15.1 & & 18.5 & 15.7 & & Frayer, 1973 \\
\hline SK-1586 & 13.7 & & & 15.0 & 14.0 & & 16.5 & 15.0 & & Frayer, 1973 \\
\hline SK-1587 & 13.3 & 13.0 & & 15.0 & 12.9 & & & & & Frayer, 1973 \\
\hline SK-1588 & 14.1 & 12.4 & & & & & & & & Frayer, 1973 \\
\hline SK-1648 & & & & 15.7 & 14.6 & & & & & Frayer, 1973 \\
\hline SK-3976 & 14.8 & 13.5 & & & & & & & & Frayer, 1973 \\
\hline SK-3976 & & & & 17.4 & 16.0 & & & & & Frayer, 1973 \\
\hline ER-729 & 15.6 & 15.7 & & 19.0 & 18.0 & & 20.5 & 18.7 & & Frayer, 1973 \\
\hline ER-801 & & & & 18.1 & 16.5 & & 18.8 & 15.5 & & Frayer, 1973 \\
\hline ER-810 & & & & & & & 17.4 & 15.6 & & Frayer, 1973 \\
\hline ER-818 & 16.4 & 15.2 & & 18.5 & 18.0 & & 21.5 & 18.4 & & Frayer, 1973 \\
\hline ER-1171/2 & & & & 18.8 & 16.9 & & & & & Frayer, 1973 \\
\hline
\end{tabular}

Material Komparasi: Pengukuran Gigi-geligi pada Australopithecines (Gracile) dalam millimeter

\begin{tabular}{|c|c|c|c|c|c|c|c|c|c|c|}
\hline \multirow[t]{2}{*}{ Spesimen } & \multicolumn{3}{|c|}{$M_{1}$} & \multicolumn{3}{|c|}{$M_{2}$} & \multicolumn{3}{|c|}{$M_{3}$} & \multirow[t]{2}{*}{ Referensi } \\
\hline & M-D & B-L & $\mathbf{H}$ & M-D & B-L & $\mathrm{H}$ & M-D & B-L & $H$ & \\
\hline Omo-75 & 15.6 & 14.1 & & 17.5 & 15.4 & & 15.1 & 14.1 & & Howell, 1969 \\
\hline Omo-Kalam 7 & 15.1 & 13.4 & & & & & & & & Howell, 1969 \\
\hline Omo-75 S.15 & 14.0 & 13.0 & & & & & & & & Howell, 1969 \\
\hline Omo-WS-508 & 13.3 & 12.2 & & & & & & & & Howell, 1969 \\
\hline
\end{tabular}




\begin{tabular}{|l|r|l|l|l|l|l|l|l|l|l|}
\hline Omo-WS-752 & 14.1 & 13.0 & & & & & & & & Howell, 1969 \\
\hline Omo-L2-89 & 13.7 & 11.5 & & & & & & & & Howell, 1969 \\
\hline Omo-L45-2 & 12.9 & 12.0 & & & & & & & & Howell, 1969 \\
\hline Omo-L51-1 & & & & 14.0 & 12.6 & & & & & Howell, 1969 \\
\hline Omo-L26-1 & & & & 15.5 & 13.0 & & & & & Howell, 1969 \\
\hline Omo-L28-30/31 & & & & 15.0 & 13.0 & & 16.7 & 12.4 & & Howell, 1969 \\
\hline OH-7 & 14.1 & 12.5 & & 15.8 & 13.8 & & & & & Frayer, 1973 \\
\hline OH-16 & 14.3 & 12.8 & & 15.3 & 14.7 & & 15.8 & 14.4 & & Frayer, 1973 \\
\hline OH-30 & 16.5 & 14.5 & & & & & & & & Frayer, 1973 \\
\hline ER-730 & 11.3 & 12.0 & & 11.6 & 11.8 & & 13.0 & 11.6 & & Frayer, 1973 \\
\hline ER-992 & 12.3 & 10.9 & & 12.8 & 12.3 & & 13.1 & 12.5 & Frayer, 1973 \\
\hline STS-4 & & & & 14.4 & 13.3 & & & & & Frayer, 1973 \\
\hline STS-6 & & & & 14.3 & 14.0 & & & & & Frayer, 1973 \\
\hline STS-7 & 14.3 & 14.0 & & 15.0 & 14.6 & & 15.3 & 14.7 & & Frayer, 1973 \\
\hline STS-9 & 14.9 & 13.0 & & & & & & & & Frayer, 1973 \\
\hline STS-18 & 15.3 & 14.5 & & & & & & & & Frayer, 1973 \\
\hline STS-24 & 13.6 & 11.4 & & & & & & & & Frayer, 1973 \\
\hline STS-36 & 11.8 & 14.6 & & 14.8 & 16.9 & & 16.3 & 17.2 & & Frayer, 1973 \\
\hline STS-52b & 13.5 & 13.1 & & 14.5 & 13.4 & & 13.8 & 12.7 & & Frayer, 1973 \\
\hline STS-55b & & & & 15.2 & 13.3 & & & & & Frayer, 1973 \\
\hline TM-1515 & 13.0 & & & 16.9 & 16.4 & & & & & Frayer, 1973 \\
\hline TM-1518 & 14.3 & 13.2 & & & & & & & & Frayer, 1973 \\
\hline Taung & & & & 16.9 & 16.4 & & & & & Frayer, 1973 \\
\hline MLD-2 & 14.7 & 14.1 & & 16.8 & 15.1 & & & & & Frayer, 1973 \\
\hline MLD-18 & 12.4 & 13.1 & & 14.6 & 14.8 & & 14.0 & 13.9 & & Frayer, 1973 \\
\hline MLD-22 & & & & 13.5 & 14.3 & & 15.8 & 15.2 & & Frayer, 1973 \\
\hline MLD-24 & & & & 15.0 & 14.0 & & & & & Frayer, 1973 \\
\hline MLD-29 & 12.5 & 13.4 & & & & & & & & Frayer, 1973 \\
\hline MLD-40 & & & & 15.0 & 13.8 & & 16.5 & 14.1 & & Frayer, 1973 \\
\hline
\end{tabular}


Material Komparasi: Pengukuran Gigi-geligi pada Homo erectus (Indonesia) dalam millimeter

\begin{tabular}{|l|l|l|l|r|r|r|r|r|r|l|}
\hline \multirow{2}{*}{ Specimen } & \multicolumn{3}{|c|}{$\mathbf{M}_{\mathbf{1}}$} & \multicolumn{3}{|c|}{$\mathbf{M}_{\mathbf{2}}$} & \multicolumn{3}{|c|}{$\mathbf{M}_{\mathbf{3}}$} & Reference \\
\cline { 2 - 10 } & $\mathbf{M - D}$ & $\mathbf{B}-\mathbf{L}$ & $\mathbf{H}$ & $\mathbf{M}-\mathbf{D}$ & $\mathbf{B}-\mathbf{L}$ & \multicolumn{1}{c|}{$\mathbf{H}$} & $\mathbf{M}-\mathbf{D}$ & $\mathbf{B}-\mathbf{L}$ & $\mathbf{H}$ & \\
\hline Sangiran 1b & & & & 13.1 & 12.8 & 6.7 & 13.6 & 12.2 & 6.3 & Widianto, 1993 \\
\hline Sangiran 5 & & & & 14.1 & 14.3 & 6 & & & & Widianto, 1993 \\
\hline Sangiran 6b & & & & 14.4 & 13.2 & 5.3 & 13.7 & 13.5 & 5.3 & Widianto, 1993 \\
\hline Sangiran 8 & & & & & & & 14.3 & 12.6 & 5.3 & Widianto, 1993 \\
\hline Sangiran 9 & & & & 13.1 & 12.3 & 5.1 & 12.2 & 12.3 & 4.6 & Widianto, 1993 \\
\hline Sangiran 21 & & & & & & & 12.0 & 10.8 & 5.9 & Widianto, 1993 \\
\hline Sangiran 22 & & & & 12.5 & 12.6 & 5.4 & & & & Widianto, 1993 \\
\hline Sangiran 24 & & & & 12.5 & 11.2 & 6.8 & 11.7 & 11.2 & 8.7 & Widianto, 1993 \\
\hline Sangiran 33 & & & & 14.2 & 13.5 & 8.7 & & & & Widianto, 1993 \\
\hline Sangiran 37 & & & & 12.3 & 11.7 & 7.1 & 10.6 & 11.1 & 5.7 & Widianto, 1993 \\
\hline Arjuna 8 & & & & 11.7 & 10.1 & & & & & Widianto, 1993 \\
\hline Arjuna 9 & & & & 13.7 & 13.6 & 6 & 13.1 & 12.7 & 6.1 & Widianto, 1993 \\
\hline Brahmana 13 & & & & 12.1 & 11.7 & 5.7 & & & & Widianto, 1993 \\
\hline Ng. 91/G10-1 & & & 11.7 & 12.3 & 7.9 & & & & Widianto, 1993 \\
\hline
\end{tabular}

Material Komparasi: pengukuran Gigi-geligi pada Gigantopithecus blacki (von Koenigswald) dalam millimeter

\begin{tabular}{|l|r|r|r|r|r|r|l|}
\hline \multicolumn{1}{|c|}{ Specimen } & \multicolumn{3}{|c|}{$\mathbf{M}_{\mathbf{2}}$} & \multicolumn{3}{c|}{$\mathbf{M}_{\mathbf{3}}$} & \multirow{2}{*}{ Reference } \\
\cline { 2 - 8 } & M-D & B-L & H & M-D & B-L & H & \\
\hline G. blacki I & & & & 22.3 & 18.5 & 11.2 & Von Koenigswald, 1952 \\
\hline G. blacki II & & & & 23.1 & 17.5 & 11.8 & Von Koenigswald, 1952 \\
\hline G. blacki IV & & & & 22.4 & 17.3 & 12.8 & Von Koenigswald, 1952 \\
\hline G. Bilaspurensis I & 18.6 & 17.4 & & & & & Simons \& Chopra, 1969 \\
\hline G. Bilaspurensis II & 21.3 & 18.9 & & & & & Simons \& Chopra, 1969 \\
\hline G. Bilaspurensis III & 21.2 & 21 & & & & & Simons \& Chopra, 1969 \\
\hline G. Bilaspurensis IV & 19.1 & 16 & & & & & Simons \& Chopra, 1969 \\
\hline
\end{tabular}

